\title{
Assessment of the Remineralisation Products Efficiency in Incipient Caries Lesions Adjacent to the Fixed Orthodontic Appliances
}

\author{
GALINA PANCU*, GIANINA IOVAN, SIMONA STOLERIU*, NICOLETA TOFAN, ANTONIA MOLDOVANU, EMILIA DIMBU, \\ GEORGIANA MACOVEI, SORIN ANDRIAN \\ Grigore T. PopaUniversity of Medicine and Pharmacy of lasi, Faculty of Dental Medicine, 16 Universitatii Str., 700115 Iasi, Romania
}

\begin{abstract}
The aim of the study is to asses, by using microhardness technique, the remineralization effect of some products used in the treatment of early dental caries adjacent to fixed orthodontic appliances. The study was performed on a group of 32 patients receiving fixed orthodontic therapy. The patients were randomly divided in two groups, accordingly to the administered preventive protocol: in group 1 (control) toothpaste Splat Professional Biocalcium (withoutfluoride) was applied twice a day; in group 2 (study group) toothpaste and mouthwash Vitis anticaries with natrium monofluorophosphate $1450 \mathrm{ppm} F$, respectively $226 \mathrm{ppm} F$, twice a day were used. After 60 days, the extraction of premolars was made and the preparation of the samples was done. The microhardness analysis was performed using the device CV 400 DAT (Namicon). The analysis of the results found lower microhardness for the samples submitted to brushing with fluoridated toothpaste and rinsing with fluoridated mouthwash solution, comparing to control (samples submitted only to brushing with non-fluoridated toothpaste). The conclusions of this study confirm the effectiveness of a proper prophylactic protocol (toothbrushing with fluoridated toothpaste, mouth rinsing with fluoridated mouthwashes) associated to the fixed orthodontics therapy, in the prevention of the early enamel demineralization onset adjacent to brackets.
\end{abstract}

Keywords: enamel demineralization, orthodontic brackets, remineralization, microhardness

Nowadays we assist to an increased demand for fixed orthodontics therapy for children, teenagers, and young adults. Despite of the high effectiveness of the fixed orthodontic treatment [1], it is recorded a high incidence of the dental and periodontal complications, especially in pourly treated cases [1,2]. The additional retention areas for the bacterial plaque due to the fixed orthodontic appliances (brackets, rings, fixed bonded retainers) contribute to the onset of quantitative and qualitative changes of the bacterial flora, increasing the pathogenity and contributing to the formation of new enamel areas vulnerable to the cariogenic attacks [3-5]. One of the most frequent complication is represented by early acute dental caries (white-spot) onset adjacent to the orthodontics brackets [1-7]. Almost one third of the patients with poor oral hygiene, receiving fixed orthodontic therapy, develop at least one carious lesion due to the bacterial plaque formed around fixed orthodontic appliances [8]. In the oral cavity, the remineralization and demineralization processes are in a permanent dynamic balance. When the cariogenic factors are involved, the demineralization processes are favoured [4, 9-12]. If the cariogenic factors are removed, the evolution of the demineralization can be stopped $[2,3$, $5,13]$.

Some researches found a fast increase of the bacterial plaque volume following the application of the fixed orthodontic appliances. Also, in these situations, the bacterial plaque has a lower $\mathrm{pH}$ comparing to the patients that are not treated by fixed orthodontic therapy [14]. The change of the bacterial flora composition was observed in the dental areas adjacent to the fixed orthodontic appliances. The levels of acidogenic bacteria (Streptococcus mutans, lactobacillus) increase significantly [15]. Thus, the evolution of the cavitated carious lesions is accelerated to the patients receiving fixed orthodontic therapy.
Despite the numerous oral hygiene products recommended for the prevention-therapeutic approach of the early enamel demineralizations associated to bacterial plaque [13, 16-18], the prevention of these carious lesions is a challenge regulated by other associated factors, as proper selection of the product and the application time of the recommended preventive method [16, 17, 19-22]. Other major factors involved are as follows: cariogenic risk, dental tissues resistance to the cariogenic attack, quantity and quality of saliva, pathogenity of the bacterial flora, diet [16, 17, 19, 22].

The aim of this study is to assess in vivo changes of the enamel associated to the retention of some orthodontic appliances and the ability of some oral hygiene products to counteract these changes.

\section{Experimental part}

The study followed all the regulations imposed by Ethics and Research Committee of Dental Medicine Faculty, Gr.T.Popa University of Medicine and Pharmacy laoi and in accordance to some published models [23].

The study was performed on a group of 32 patients (aged between 18 and 28 years), receiving fixed orthodontic therapy. All patients signed an informed consent. The inclusion and exclusion criteria for the patients' selection are presented in table 1.

The research protocol is described in table 2.

Before the beginning of the study, it were performed the professional mechanic toothbrushing and the assessment of the enamel quality of the premolars, using KAVO DiagnoPen (KaVo Germania). Values under 13 confirmed the absence of hypoplasia or demineralization.

The indications for proper oral hygiene were given to all patients. The use of the oral hygiene products was recommended, accordingly to the preventive protocol. The patients were divided in two groups: control; study groups.

* email: pancu.galina@yahoo.com; stoleriu_simona@yahoo.com

REV.CHIM.(Bucharest) $70 \diamond$ No.8 $2019 \quad$ http://www.revistadechimie.ro 
Table 1

PATIENTS'ASSESSMENTCRITERIA

\begin{tabular}{|c|c|}
\hline Inclusion criteria & Exclusion criteria \\
\hline $\begin{array}{l}\text { - patients receiving fixed orthodontic therapy } \\
\text { - } \text { indication for extraction of first permanent premolars } \\
\text { changes, enamel defects, non-cariogenic lesions } \\
\text { - DiagnoPen values (first premolars) }<13 \\
\text { - medium cariogenic risk } \\
\text { normal values range of the stimulated and resting salivary } \\
\text { flow rate, } \\
\text { - } \text { normal saliva buffering capacity }(6,5-7,2) \\
\text { - } \text { absence of allergic reactions to remineralization products }\end{array}$ & $\begin{array}{l}\text { - high cariogenic risk } \\
\text { - } \quad \text { active dental caries } \\
\text { noncariogenic lesions (fluorosis, } \\
\text { hypoplasia, erosions, dischromia, } \\
\text { traumatic lesions, etc) } \\
\text { - poor oral hygiene } \\
\text { - altered salivary function } \\
\text { allergic reactions to remineralization } \\
\text { - } \text { products } \\
\text { - medical treatments } \\
\text { - unforeseen secondary reactions }\end{array}$ \\
\hline
\end{tabular}

Table 2

WORKING PROTOCOL



- Group 1 (control)- the patients received toothpaste Splat Professional Biocalcium (without fluoride), twice a day (morning, evening);

- Group 2 (study group)- the patients received toothpaste and mouthwash Vitis anticariesce (with sodium monofluorophosphate $1450 \mathrm{ppm} F$, respectively $226 \mathrm{ppm}$ F), twice a day (morning, evening).

For the assessment of the protective effects of the various fluoride products, we selected the toothpastes described in the table 3 , with and without fluoride, and various concentrations of the active agents.

The orthodontic brackets were bonded with Transbond Plus (3M Unitek, Monrovia, CA, USA). Phosphoric acid 37\% (3M ESPE, St Paul, MN, USA) was used for $15 \mathrm{~s}$ for enamel etching. The teeth were rinsed for $30 \mathrm{~s}$ and then were dried for $20 \mathrm{~s}$. The adhesive system was applied accordingly to the producer recommendations. The composite resin was applied on bracket that was positioned and maintained to the enamel surface under pression. The excess was removed, and the composite resin was photopolymerized $10 \mathrm{~s}$ on the median area and $10 \mathrm{~s}$ on the distal area with photopolymerization lamp Elipar Freelight2 (3M-Espe). The patients were asked to use the assigned oral hygiene products and to perform toothbrushing twice daily.
For the testing procedure, 64 brackets were applied on the first permanent premolars included in study, in each group ( 32 maxillary premolars, 32 mandibular premolars, in all groups). After 60 days, the teeth were extracted and stored in refrigerator covered in vials with $2 \%$ phormaldehyde, $\mathrm{pH}=7,0$. The teeth were prepared for microhardness testing, according to the protocol established by Uysalt T. in 2011 [24]. Immediately after extraction the teeth were washed to remove all traces of blood, soft tissue, and bacterial biofilm. The teeth were examined for fissures or other defects (early caries, hypoplasia). The teeth with visible defects were excluded from study. The teeth were stored in normal saline to room temperature untill the beginning of the study. The teeth were cut with diamond discs to low speed (Extec Corp, Enfield, CT,USA), under water cooling. The root was removed and the crown was cut mesio-distally to obtain two halves: a buccal sample and an oral sample. These two halves were cut in two horizontal planes, above the bracket and under the bracket. Thus, it were obtained two samples (cervical, occlusal). All samples were polished with abrasive discs (320, 600, and 1200 grit) and polished with a $1 \mathrm{~mm}$ diamond spray and a cloth polishing disc (Buehler). All surfaces were examined using a microscope 
Table 3

ORAL HYGIENE PRODUCTSUSEDIN STUDY

\begin{tabular}{|l|l|l|l|l|}
\hline Nr. & $\begin{array}{l}\text { Commercial } \\
\text { product: }\end{array}$ & $\begin{array}{l}\text { Fluoride } \\
\text { concentration: }\end{array}$ & Active ingredients: & Manufacturer: \\
\hline $\begin{array}{l}\text { Control } \\
\text { Group 1 }\end{array}$ & $\begin{array}{l}\text { Toothpaste Splat } \\
\text { Professional } \\
\text { Biocalcium }\end{array}$ & No fluoride & $\begin{array}{l}\text { Calcium Lactate, } \\
\text { Hydroxyapatite. }\end{array}$ & $\begin{array}{l}\text { Splat-Cosmetica, LTD, } \\
\text { Moscow, Russia. }\end{array}$ \\
\hline Study Group 2 & $\begin{array}{l}\text { Toothpaste Splat } \\
\text { Vitis anticaries }\end{array}$ & $1450 \mathrm{ppm} \mathrm{F}$ & $\begin{array}{l}\text { Sodium } \\
\text { Monofluorophosphate } \\
\text { (Dentaid tehnology } \\
\text { nanorepair) }\end{array}$ & $\begin{array}{l}\text { Splat-Cosmetica, } \\
\text { DENTAID S.L., Spain }\end{array}$ \\
& $\begin{array}{l}\text { Mouthwash } \\
\text { Vitis anticaries }\end{array}$ & $226 \mathrm{ppm} \mathrm{F}$ & $\begin{array}{l}\text { Sodium } \\
\text { Monofluorophosphate } \\
\text { (Dentaid tehnology } \\
\text { nanorepair) }\end{array}$ & $\begin{array}{l}\text { Splat-Cosmetica, } \\
\text { DENTAID S.L., Spain }\end{array}$ \\
\cline { 2 - 5 } & & & \\
\hline
\end{tabular}

(Siemens, Germany) at 100x magnification. Any sample with surface defects was excluded. The samples were embedded in epoxydic resin in metallic cylinders, and the enamel microhardness was.

In both groups the values of the microhardness parameters were evaluated in relation to the localisation (distance of $0 \mu \mathrm{m}, 100 \mu \mathrm{m}$ and $200 \mu \mathrm{m}$ from the position of the bracket occlusally and cervically), and to the depth of enamel area (at 10, 20, 30, 40, 50, and 60 $\mathrm{mm}$ from enamel surface, on occlusal and cervical horizontal sections).

The enamel microhardness was measured with digital device CV 400 DAT (Namicon). The indentations were performed with a $50 \mathrm{~g}$ contact force. For each sample, 5 indentations were performed, and Vicker hardness number (VHN) was recorded for each of them. For each sample the microhardness value was recorded as mean of 5 measurements. The acceptance criteria of an indentation were as follows: sharp on diagonally edges, regulated diagonally aspect, the absence of irregularities in the tested area.

SPSS software, version 11.5 was used to analyse the data. The mean, standard deviation, maximum, and minimum measures in the two groups. We examined the findings of this study by, ANOVA, Tukey's tests and paired t-test where $\alpha<0.05$ was considered significant. ShapiroWilks normality test and the Levene variance homogeneity test were applied to the microhardness data. The data showed normal distribution, and there was homogeneity of variances between the groups.

\section{Results and discussions}

In both groups the values of the microhardness parameters varied in relation to the localisation and to the depth of enamel area.

The results in relation to localisation are presented in table 4. Significant statistical values were recorded to samples in group 1 localised as follows: buccal surface, occlusal area, closed to bracket $(0 \mu \mathrm{m})$, cervical area with the same distance $(0 \mu \mathrm{m})$. For the other locations the recorded values were not significantly statistical.

The mean values varied in the occlusal position $(0 \mu \mathrm{m})$ from 269.56 in Group 1 to 319.89 in Group 2. In the cervical position $(0 \mu \mathrm{m})$ the mean values varied from 274.12 in Group 1 to 319.71 for Group 2. The most important demineralization areas are localized in the immediate surrounding of the brackets for the control group. No decrease of the microhardness for the samples on the study group submitted to the action of fluoridated products was recorded.

The comparative analysis of the microhardness values in relation to the depth of enamel area is presented in table 5. Significantstatistical values were recorded only for Group 1 (control), in the surface layers (10 and $20 \mu \mathrm{m})$. The microhardness values are not significantly statistical for the samples from Group 2, submitted to the remineralization therapy with fluoridated products, and for the samples from Group 1, with depths over 30 $\mu \mathrm{m}$.

The mean values for depth $10 \mu \mathrm{m}$ in enamel, varied as follows: 269.19 for Group 1 (control) and 304.221 for Group

Table 4

DESCRIPTIVE STATISTICSAND MULTIPLE COMPARISONSOF MICROHARDNESS (VHN) FOR STUDY GROUPS AT DIFFERENT LOCALIZATION

\begin{tabular}{|c|c|c|c|c|c|c|c|c|c|}
\hline \multirow[t]{2}{*}{ Group } & & \multicolumn{8}{|c|}{$\begin{array}{l}\text { Interaction of active products } \\
\text { Type/Localization }\end{array}$} \\
\hline & & $\begin{array}{l}0 \\
200 \mu \mathrm{m}\end{array}$ & $\begin{array}{l}0 \\
100 \mu \mathrm{m}\end{array}$ & $\begin{array}{l}0 \\
0.0 \mu \mathrm{m}\end{array}$ & UB & $\begin{array}{l}\mathrm{C} \\
0.0 \mu \mathrm{m}\end{array}$ & $\begin{array}{l}\mathrm{C} \\
100 \mu \mathrm{m}\end{array}$ & $\begin{array}{l}\mathrm{C} \\
200 \mu \mathrm{m}\end{array}$ & Or \\
\hline \multirow[t]{2}{*}{ Group 1} & Mean & 308.231 & 307.161 & 269.561 & 321.139 & 274.124 & 312.639 & 313.246 & 324.178 \\
\hline & SD & 17.891 & 22.187 & 21.831 & 18.341 & 23.541 & 22.987 & 19.571 & 16.467 \\
\hline \multirow[t]{3}{*}{ Group 2} & Mean & 316.918 & 318.158 & 319.141 & 321.893 & 319.711 & 316.981 & 319.785 & 323.964 \\
\hline & SD & 17831 & 13.981 & 15.845 & 16.893 & 17.945 & 16.183 & 17.459 & 14.982 \\
\hline & $\begin{array}{l}\text { Multiple } \\
\text { Comparisons * }\end{array}$ & $\mathrm{NS}$ & $\mathrm{NS}$ & 8 & $\mathrm{NS}$ & 8 & $\mathrm{NS}$ & $\mathrm{NS}$ & $\mathrm{NS}$ \\
\hline \multicolumn{10}{|c|}{$\begin{array}{l}\text { O (oclusal), UB (under bracket), C (cervical), Or (oral) } \\
\text { *Tukey HSD test. NS indicates not significant. } \\
\text { * Statistically significant }(\mathrm{P}<.05) \text {. }\end{array}$} \\
\hline
\end{tabular}


2 (study group). The mean values for depth $20 \mu \mathrm{m}$ in enamel, varied as follows: 277.621 for Group 1 (control) and 308.431 for Group 2 (study group).

These results show the protective effect of the fluoridated products for the samples from Group 2 (study group), preventing the demineralization and the decrease of the enamel surface microhardness.

The comparative analysis of the microhardness values in relation to the localization and demineralization depth in enamel found significant statistical values for depths 10 $\mu \mathrm{m}$ and $20 \mu \mathrm{m}$, only for occlusal and cervical localization adjacent to brackets $(0 \mu \mathrm{m})$ (table 6$)$.

The minimal values for occlusal depth $10 \mu \mathrm{m}$, varied between 186.16 for Group 1 (control) and 276.34 for Group 2 (study group). The minimal values for cervical varied between 149.98 for Group 1 (control) and 277.99 for Group 2 (study group). The minimal values for depth $20 \mu \mathrm{m}$ varied as follows: for occlusal, 219.78 for Group 1 (control), and 309.21 for Group 2 (study group); for cervical, 178.18 for Group 1 (control), and 289.31 for Group 2 (study group) (table 6).

The maximal values for occlusal depth $10 \mu \mathrm{m}$, varied between 224.98 for Group 1 (control) and 312.94 for Group 2 (study group). The maximal values for cervical varied between 193.56 for Group 1 (control) and 316.89 for Group 2 (study group). The maximal values for depth $20 \mu \mathrm{m}$ varied as follows: for occlusal, 261.98 for Group 1 (control), and 343.09 for Group 2 (study group); for cervical, 234.12 for Group 1 (control), and 321.79 for Group 2 (study group) (table 6).

The most frequent complication associated to the fixed orthodontic therapy is early dental caries (white-spot) produced by enamel demineralization initiated by the retention of the bacterial plaque around the fixed orthodontic appliances (brackets, rings, fixed bonded retainers) as well as poor oral hygiene [1, 10, 14, 25]. The brackets and orthodontic molar rings create retentive spaces for bacterial plaque due to the limited access for oral hygiene $[1,25,26]$.

These additional retention elements are associated with vulnerable dental areas to the cariogenic attacks and determine quantitative and qualitative changes of the microbial flora. It was recorded the increase of the pathogenicity of the cariogenic bacteria, especially for Streptoccocus mutans $[3-5,8,10,12]$. The early dental caries are opaque white-spot areas, having an increased roughness at the palpation with probe. They are localised on the cervical areas or around the brackets or other

Table 5

DESCRIPTIVE STATISTICSAND MULTIPLE COMPARISONS OF MICROHARDNESS (VHN) FOR GROUPS AT DIFFERENT DEPTHS OF SURFACE

\begin{tabular}{|c|c|c|c|c|c|c|c|}
\hline \multirow[t]{2}{*}{ Group } & & \multicolumn{6}{|c|}{$\begin{array}{l}\text { Interaction of active products } \\
\text { Type/Depth, } \mu \mathrm{m}\end{array}$} \\
\hline & & 10 & 20 & 30 & 40 & 50 & 60 \\
\hline \multirow[t]{2}{*}{ Group 1} & Mean & 269.198 & 277.621 & 289.341 & 319.987 & 329.321 & 338.169 \\
\hline & SD & 7.341 & 8.342 & 8.741 & 9.562 & 8.397 & 9.309 \\
\hline \multirow[t]{3}{*}{ Group 2} & Mean & 304.221 & 308.431 & 312.108 & 321.372 & 329.167 & 334.112 \\
\hline & SD & 8.378 & 9.922 & 9.426 & 8.905 & 8.721 & 7.782 \\
\hline & $\begin{array}{l}\text { Multiple } \\
\text { comparisions* }\end{array}$ & * & * & NS & $\mathrm{NS}$ & $\mathrm{NS}$ & $\mathrm{NS}$ \\
\hline
\end{tabular}

Table 6

DESCRIPTIVE STATISTICS AND MULTIPLE COMPARISONS OF MICROHARDNESS (VHN) FOR STUDY GROUPS AT DIFFERENT LOCALIZATION AT DEPTH OF $10 \mu \mathrm{m}$ AND $20 \mu \mathrm{m}$

\begin{tabular}{|c|c|c|c|c|c|c|c|c|c|c|}
\hline & & & \multicolumn{8}{|c|}{ Localization } \\
\hline $\begin{array}{l}\text { Depth, } \\
\text { mm }\end{array}$ & Group & & $\begin{array}{l}O \\
200 \mu \mathrm{m}\end{array}$ & $\begin{array}{l}0 \\
100 \mu \mathrm{m}\end{array}$ & $\begin{array}{l}0 \\
0.0 \mu \mathrm{m}\end{array}$ & UB & $\begin{array}{l}\mathrm{C} \\
0.0 \mu \mathrm{m}\end{array}$ & $\begin{array}{l}\mathrm{C} \\
100 \mu \mathrm{m}\end{array}$ & $\begin{array}{l}\mathrm{C} \\
200 \mu \mathrm{m}\end{array}$ & Or \\
\hline \multirow{8}{*}{10} & \multirow{4}{*}{$\begin{array}{l}\text { Group } \\
1\end{array}$} & Mean & 297.78 & 293.42 & 208.76 & 301.12 & 179.21 & 283.18 & 301.34 & 318.19 \\
\hline & & SD & 8.207 & 9.812 & 8.891 & 8.631 & 9.129 & 10.581 & 9.899 & 8.781 \\
\hline & & $\min$ & 277.15 & 269.13 & 186.16 & 284.51 & 149.98 & 249.98 & 281.78 & 298.12 \\
\hline & & $\max$ & 311.67 & 308.98 & 224.98 & 324.98 & 193.56 & 301.67 & 315.79 & 332.17 \\
\hline & \multirow{4}{*}{$\begin{array}{l}\text { Group } \\
2\end{array}$} & Mean & 304.34 & 312.98 & 298.21 & 312.67 & 294.56 & 304.45 & 303.98 & 319.78 \\
\hline & & SD & 7.543 & 9.752 & 7.498 & 8.897 & 9.019 & 8.893 & 8.541 & 8.598 \\
\hline & & $\min$ & 287.92 & 294.21 & 276.34 & 297.67 & 277.99 & 291.01 & 282.67 & 304.78 \\
\hline & & $\max$ & 318.34 & 331.89 & 312.94 & 331.99 & 316.89 & 327.54 & 317.39 & 337.59 \\
\hline \multicolumn{3}{|c|}{$\begin{array}{l}\text { Multiple } \\
\text { comparisions* }\end{array}$} & $\mathrm{NS}$ & $\mathrm{NS}$ & 8 & $\mathrm{NS}$ & 8 & $\mathrm{NS}$ & $\mathrm{NS}$ & NS \\
\hline \multirow{8}{*}{20} & \multirow{4}{*}{$\begin{array}{l}\text { Group } \\
1\end{array}$} & Mean & 314.54 & 315.89 & 241.79 & 324.56 & 214.72 & 298.89 & 314.71 & 324.61 \\
\hline & & SD & 6.381 & 9.109 & 8.731 & 9.198 & 9.911 & 8.989 & 9.268 & 8.731 \\
\hline & & $\min$ & 294.23 & 281.91 & 219.78 & 308.56 & 178.18 & 281.33 & 296.71 & 307.34 \\
\hline & & $\max$ & 327.56 & 326.89 & 261.98 & 339.41 & 234.12 & 316.68 & 329.91 & 339.71 \\
\hline & \multirow{4}{*}{$\begin{array}{l}\text { Group } \\
2\end{array}$} & Mean & 315.67 & 323.12 & 318.46 & 320.99 & 307.59 & 316.27 & 312.89 & 321.59 \\
\hline & & SD & 6.409 & 7.389 & 7.871 & 9.810 & 7.217 & 9.561 & 8.918 & 8.571 \\
\hline & & $\min$ & 298.12 & 312.11 & 309.21 & 305.21 & 289.31 & 303.71 & 299.89 & 307.74 \\
\hline & & $\max$ & 331.44 & 338.85 & 343.09 & 337.69 & 321.79 & 331.85 & 333.76 & 341.78 \\
\hline \multicolumn{3}{|c|}{$\begin{array}{l}\text { Multiple } \\
\text { comparisions* }\end{array}$} & $\mathrm{NS}$ & $\mathrm{NS}$ & 8 & $\mathrm{NS}$ & 8 & $\mathrm{NS}$ & $\mathrm{NS}$ & $\mathrm{NS}$ \\
\hline
\end{tabular}


retention orthodontic elements or on buccal surfaces that are usually considered resistent areas to cariogenic attack $[3-5,22,27]$. Despite the onset of early dental caries is observed even at only 4 weeks after the application of the fixed orthodontic appliances [6,25,26], our clinical study was performed during 60 days to exclude errors related to time.

Richter et al. Detected white-spot to almost $75 \%$ of the patients submitted to fixed orthodontic therapy $[8,26]$. The prevention of the white-spot onset must include the increase of the patients' awareness regarding the importance of the oral hygiene $[3-7,28,29]$. Both patients and orthodontist can collaborate to minimize the risk for the onset of the enamel white-spots [20,21, 29, 30].

Most studies, regarding the changes of the hard dental tissues associated to fixed orthodontic therapy, were performed in vitro, on bovine or human extracted teeth using SEM, surface profilometry, laserfluorescence) $[5,13$, $20,21,27,29]$.

To avoid the errors associated to in vitro model, we tested Vickers microhardness on teeth extracted for orthodontic reasons. The in vivo study allowed the assessment of the changes of the vital teeth, and requested a good cooperation with patients. Because the protected enamel surface allowed the accumulation of thick plaque, no other site was at risk of caries with this procedure. The oral hygiene characteristics are not always homogeneously distributed over the within-patient experimental units, and this heterogeneity can reduce the efficiency of split-mouth designs.

In our study, it were recorded lower micorhardness values in the occlusal areas of the buccal surfaces, comparing to the cervical areas; similar results are reported by Uysal T. in 2011 [24], and Pascotto R.C. et all, in 2014 [31]. For in vivo conditions, the explanation is related to higher accumulation of the bacterial plaque and to the limited access of the oral hygiene tools in this area.

In our study, the demineralization depth was limited to $20 \mu \mathrm{m}$, while other similar studies reported that demineralization depth reached 30um, [31-33], or even $75 \mu \mathrm{m}$ [34]. The lower demineralization depth in our in vivo study can be explained by the partial removal of the bacterial plaque by toothbrushing, The differences between the microhardness values recorded in control and study groups demonstrate the contribution of fluoride (fluoridated toothpaste, fluoridated mouthwash) as well as the effectiveness of fluoride remineralization capacity to the subjects from the study group.

Regarding the correlation between the demineralization degree and the distance to brackets, it was recorded a significant decrease of the microhardness in point 0 , both cervical, and occlusal, resultsimilar to those found by Uysal T., in 2011 [24], but different by the results presented by other researchers [31, 33, 34].

In our study, it was selected a remineralization product with $1450 \mathrm{ppm} \mathrm{F}$, a concentration that was proved to be effective in other studies [33-37]. Faller R.V. [16] demonstrated the role of the fluoride concentration and the active compounds of the toothpaste. This study found that, despite the inclusion of stannous fluoride in various oral hygiene products, the capacity of these products to release stannous fluoride and to protect the enamel surface is very different and strongly related to the productformula. The study concluded that the effectiveness of each oral hygiene product to protect against demineralization must be reviewed [16].

An in vitro study performed by Hirata E. in 2013 [18], demonstrated positive results related to the use of a toothpaste with low concentration of fluoride $(450 \mathrm{mgF} / \mathrm{g}$, natrium fluoride) in combination with calcium citrate (Cacit) and sodium trimethaphosphate (TMP), due to the association between the active agents of the toothpaste.

In our study, we demonstrated that the tendency of the bacterial plaque to accumulate around the fixed orthodontic appliances is closely related to ultrastructural changes associated to lower enamel microhardness. A toothpaste with fluoride associated to a mouthwash allowed better protection against this effect.

Despite the recent advances, the prevention of the enamel demineralization during the fixed orthodontic therapy is one of the biggest challenges, both for the general dentists and orthodontists. Each patient needs an oral hygiene protocol that must be followed both at home and in dental office. This protocol must be individualized aiming to hinder the onset of early dental caries during the fixed orthodontic therapy. The protocol also must be effective in the remineralization of white-spot and to prevent the evolution to cavitary dental caries.

\section{Conclusions}

The conclusions of this study confirm the effectiveness of a proper prophylactic protocol (toothbrushing with fluoridated toothpaste, mouth rinsing with fluoridated mouthwashes) associated to the fixed orthodontics therapy, in the prevention of the early enamel demineralization onset adjacent to brackets. The analysis of the results found lower microhardness for the samples submitted to brushing with fluoridated toothpaste and rinsing with fluoridated mouthwash solution, comparing to control (samples submitted only to brushing with nonfluoridated toothpaste).

\section{References}

1.CHAPMAN, J.A., ROBERTS, W.E., ECKERT, G.J ., Am. J. Orthod. Dentofac. Orthop., 138, 2010, p.188.

2.BISHARA, S.E., OSTBY, A.W., Semin. Orthod., 14, 2008, p.174.

3.PANCU, G., ANDRIAN, S., IOVAN, G., GHEORGHE, A., TOPOLICEANU, C., MOLDOVANU, A., GEORGESCU, A., TESLARU, S., STOLERIU, S., RJOR, 6, no. 1, 2014, p. 25.

4.MACOVEI, G., ANDRIAN, S., IOVAN, G., GHEORGHE, A., NICA, I., TOPOLICEANU, C., BOLAT, M., TOFAN, N., STOLERIU, S., PANCU, G., RJOR, 8, no.4, 2016, p. 52.

5.PANCU, G., ANDRIAN, S., STOLERIU, S., GHEORGHE, A., NICA, I., TOPOLICEANU, C., MOLDOVANU, A., TOFAN, N., IOVAN, G., RJOR, 9 , no.2, 2017, p. 9.

6.STOLERIU, S., IOVAN, G., GEORGESCU, A., SANDU, A.V., ROSCA, M., ANDRIAN, S., Rev. Chim. (Bucharest), 63, no. 1, 2012, p. 68.

7.STOLERIU, S., IOVAN, G., PANCU, G., GEORGESCU, A., SANDU, A.V., ANDRIAN, S., Rev. Chim. (Bucharest), 63, no. 11, 2012, p. 1120.

8.LOVROV, S., HERTRICH, K., HIRSCHFELDER, U., J. Orofac. Orthop., 68, 2007, p. 353.

9.ANDRIAN, S., IOVAN, G., TOPOLICEANU, C., MOLDOVAN, A., STOLERIU, S., Rev. Chim. (Bucharest), 63, no. 12, 2012, p. 1231.

10. GHIORGHE, C.A., STOLERIU, S., PANCU, G., TOPOLICEANU, C., SANDU, A.V., ANDRIAN, S., Rev. Chim.(Bucharest), 65, no. 9, 2014, p. 1021.

11.STOLERIU, S., IOVAN, G., GHIORGHE, C.A., NICA, I., PANCU, G., GEORGESCU, A., ANDRIAN, S., Rev. Chim(Bucharest)., 66, no.11, 2015, p.1772.

12.STOLERIU, S., ANDRIAN, S., PANCU, G., NICA, I., IOVAN, G., RJ OR, 8, no. 4, 2016, p. 12.

13.CHIN, M.Y.H., SANDHAM, A., RUMACHIK, E.N., Am. J. Orthod. Dentofac. Orthop., 136, 2009, p. 547.

14.BENSON, P.E., SHAH, A.A., MILLETT, D.T., DYER, F., PARKIN, N., VINE, R.S., J. Ortod., 32, 2005, p.102.

15.LUNDSTROM, F., KRASSE, B., Europ. J. Ortod., 9, 1987, p.109.

16.FALLER, R.V., EVERSOLE, S.L., J. Clin. Dent., 24, no.1, 2013, p. 25. 
17.WHITE, A.J ., J ONES, S.B., BARBOUR, M.E., J. Dent., 40, no. 8, 2012, p. 654.

18.HIRATA, E., DANELON, M., RODRIGUES, FREIRE, I., BOTAZZO, DELBEM, A.C., Braz. Dent. J., 24, no. 3, 2013, p. 25.

19.ROBERT, V., FALLER, R.V., SANDRA, L., EVERSOLE, S.L., SAUNDERS BURKHARDT, K., I.Dent. J., 6, no. 1, 2014, p. 29.

20.GEIGER, A.M., GORELICK, L., GWINNET, A.J., Am. J. Orthod. Dentofac. Orthop., 101, 1992, p. 403.

21.GEIGER, A.M., GORELICK, L., GWINNET, A.J ., Am. J. Orthod. Dentofac. Orthop., 93, 1988, p. 29.

22.MAXFIELD, B.J., HAMDAN, A.M., TUFEKÇI, E., SHROFF, B., LINDAUER, S.) ., Am. J. Orthod. Ortoped. Dentofac., 141, 2012, p. 337. 23.AGHEORGHIESEI CORODEANU, D.T., POROCH, V., 6th LUMEN International Conference on Rethinking Social Action Core Values, 16-19 April 2015, Iasi, Romania, Rethinking Social Action. Core Values, p. 33.

24.UISAL, T., AKKURT, M.D., AMASYALI, M., OZCAN, S., YAGCI, A., BASAK, F., SAGDIC, D., Angle Orthodontist, 81, no. 2, 2011, p.319

25. OGAARD, B., LARSSON, E., HENRIKSSON, T., BIRKHED, D., BISHARA, S.E., Am. J. Orthod. Dentofac. Orthop., 120, 2001, p. 28. 26.RICHTER, A.E., ARRUDA, A.O., PETERS, M.C., Am. J. Orthod. Dentofac. Orthop., 139, 2011, p. 657.
27.LUCCHESE, A., BERTACCI, A., CHERSONI, S., PORTELLI, M., Europ. J. Ped. Dent., 13, 2012, p. 231.

28.CZOCHROWSKA, E.M., OGAARD, B., DUSCHNER, H., J. Orofac. Orthop., 59, 1998, p. 265.

29.DEMITO, C.F., VIVALDI-RODRIGUES, G., RAMOS, A.L., BOW MAN, S.J., Orthod Craniofac Res, 7, 2004, p. 205.

30. GIZANI, R., South Eur. J. Orthod. Dentofac. Res., 1, 2014, p. 3. 31.PASCOTTO, R.C., NAVARRO, M.F.L., CAPELOZZA, FILHO, L., CURY, J.A.,

Am. J. Orthod. Dentofacial Orthop., 125, 2004, p. 36.

32.GORTON, J., FEATHERSTONE, J.D.B., Am. J. Orthod. Dentofacial Orthop., 123, 2003, p. 10.

33.FEATHERSTONE, J.B.D., TEN CATE, J.M., SHARIATI, M., ARENDS, J., Caries Res.

17, 1983, p.385.

34.DE MOURA, M.S., DE MELO, SIMPLICIO, A.H., CURY, J.A., Am J Orthod Dentofacial Orthop., 130, 2006, p. 357.

35.AMMARI, A.B., BLOCH-ZUPAN, A., ASHLEY, P.F., Caries Res., 37, no. 2, 2003, p. 85.

36.TWETMAN, S., AXELSSON, S., DAHLGREN, H., Acta Odontol. Scand., 61,2003, p. 347.

37.FEATHERSTONE, J.D.B., Community Dental Oral Epidemiol., 27, 1999, p. 31.

$\overline{\text { Manuscript recived:11.01.2019 }}$ 